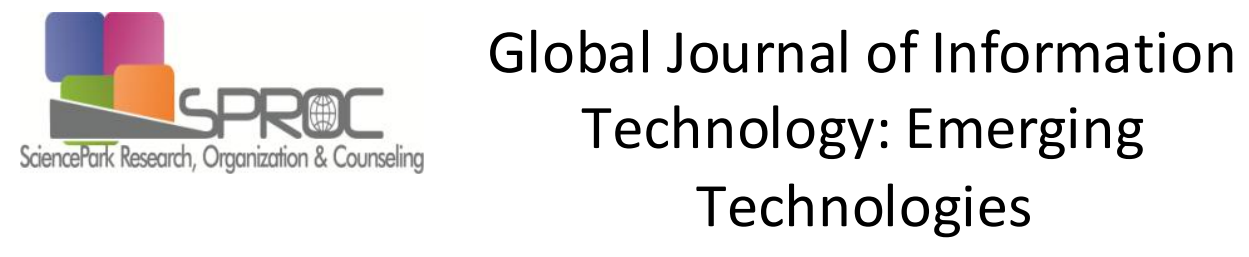

\title{
Graphic representation of open and distance education history
}

Filiz Mete*, Faculty of Education, Department of Teaching Methods and Language Education, Bulent Ecevit University, 67100, Zonguldak, Turkey.

Serife Buyukkose, Faculty of Science, Department of Mathematics, Gazi University, Turkey.

Ozlem Cakir, Faculty of Education Sciences, Department of Computer and Teaching Technology, Ankara University, Turkey.

Ummugulsum Can deger, Department of History, MEB, Turkey.

\section{Suggested Citation:}

Mete, F., Buyukkose S., Cakir, O. \& Candeger, U. (2017). Graph representation of open and distance education history. Global Journal of Information Technology: Emerging Technologies. 7(3), 92-98.

Received June 14, 2017; revised September 11, 2017; accepted November 9, 2017.

Selection and peer review under responsibility of Prof. Dr. Dogan Ibrahim, Near East University, North Cyprus.

${ }^{\circledR} 2017$ Academic World Education \& Research Center. All rights reserved.

\section{Abstract}

Nowadays, learning and instruction take place independent of time and space through the distance education system, wherein courses are conducted completely online through network technologies using interactive video-based instructional materials. This study examines the open and distance education system that was a part of the history of education in the Turkish republic firs t a t uni versities, and then in high sch ools and seconda ry schools. It is aimed to na rra te the history of open and distance education using graph theory trees in order to provide a better understanding of this process. Within this context, the project YAYÇEP may be mentioned. Historical developments can be narrated in a chronological order through graph theory trees, and this makes it possible to see the big picture. Open and distance education is discussed, historical information is given and, finally, a graph theory tree drawn using the graph theory is used to explain the topic.

Keywords: Distance education, open education, graph the ory, the his tory of dis tance education.

* ADDRESS FOR CORRESPONDENCE: Filiz Mete, Faculty of Education, Department of Teaching Methods and Language Education, Bulent Ecevit Uni versity, 67100, Zonguldak, Turkey

E-mail address: filizme te @beun.edu.tr 
Mete, F., Buyukkose S., Cakir, O. \& Candeger, U. (2017). Graph representation of open and distance education history. Global Journal of Information Technology: Emerging Technologies. 7(3), 92-98.

\section{Introduction}

Distance education is a form of learning and teaching in which students and teachers do not interact face to face. Mass media devices are used to perform educational activities, which are independent of the time and physical location. One or more media devices such as printed and written sources, audio and video recordings, telephone conversations, and computer communication could be used for effective communication and interaction. Learning and teaching are performed indirectly via media devices (Somuncuoglu, 2005).

Models of distance education have been determined based on technological developments of the materials used in distance education. Somuncuoglu (2005) examined distance education models in five generations. The first generation of distance education technology was by postal correspondence. This was followed by the second generation, defined by multi or mass media. Third-generation distance education introduced interactive technologies: first audio, then text, video and finally webbased teleconferencing. The term flexible learning was used for the fourth generation and intelligent flexible learning for the fifth generation. Printed materials were used in postal correspondence. Audio recording tapes, recording and playing videotapes, computer-based materials, and interactive videos besides printed materials were used in the multi-media model. Audio and visual teleconferences, television and radio broadcasts were used as an extra, along with other materials. Online interactive multimedia, web-based resources and the Internet were used in the flexible learning model. Finally, interactive multimedia, web-based resources, auto prompt response systems, premises portals and long-distance synchronised videos were used in the intelligent flexible learning model.

The term 'Distance Education' was first used in the 1892 catalogue of Wisconsin University, and then it was used in 1906 in an article written by William Lighty, who is the administrator of the same university (Isman, 2011).

Nowadays, educational technologies have been used together with conventional educational methods and computer and technology-based education increases the productivity in education and helps students learn more efficiently. Massive open online courses also embrace advanced learning environments, which are customised to the unique characteristics and needs of different individuals (Kesim \& Altinpulluk, 2014). The use of technology is controlled by the teacher in environments where there is a face-to-face interaction between the student and the teacher.

However, individuals are responsible for their own education in 'Distance Education'. They plan and perform their own learning. Course materials are delivered to students via the Internet in distance education. They can follow courses through Internet connections.

Although distance education was first used as a term in 1892, first studies date a long way back. Distance education initially started as 'Steno Lessons' in 1728 in the Boston newspaper in the 18th century. 'Composition Lessons by Postal Correspondence' were given to women by Sweden University in 1833 in the 19th century. Isaac Pitman, who is considered to have been the first modern educator of distance education, started to teach stenography through letters in England in 1840. The department of postal correspondence was opened at the University of Chicago in 1892. An institution named Hermands, which gave language education and had a remarkable place in distance education, was established in Sweden in 1898. The postal correspondence primary school education was first started in the USA at the beginning of the 20th century in 1906. In 1919, the radio started to be used in distance education along with postal correspondence. A radio station was opened and the number of stations reached 176 within a year. High-school education started to be given by postal correspondence in the USA in 1923. IOWA University in the USA started using television in distance education between 1932 and 1937. Distance education was used to prevent students from failing their studies during the years of the second world war in France in 1939. In 1960, the British Open University was established in England (Degimenci, 2013). 
Mete, F., Buyukkose S., Cakir, O. \& Candeger, U. (2017). Graph representation of open and distance education history. Global Journal of Information Technology: Emerging Technologies. 7(3), 92-98.

In Turkey, studies of distance education started in the later years. Some experimental practices were done to increase the literacy level because of the low level of literacy and the adaptation period to a new alphabet between 1927 and 1960. Some studies were done for a reformation in establishing more universities and arranging postal correspondence courses between 1933 and 1934. Postal correspondence for distance education trials started in 1950. In 1951, the Ministry of National Education established the Center of Educational Films and started studies to improve distance and informal education. Arrangements for foreign language and vocational courses were started by FONO in 1953. The first practices were carried out by the Research Institution on Banking and Trade Law, Ankara University Law Faculty in 1956. Postal correspondence was used to give the opportunity to vocational high-school graduates to have higher education (Simsek, 2005). The Center of Postal Correspondence was established by Ministry of National Education in 1960. This centre was organised as the General Directorate in 1966 and made an attempt to systematise informal education. The Center of Postal Correspondence for higher education was established in 1974 but later its name was changed to the Informal Higher Education Center. Vocational and Technical Open High School entered into service in 1974 (MNE/YAYKUR). After the right was given to Turkish universities to have open education by the 5th and 12th items of the law 2547, enacted on 6 November 1981, this duty was given to Anadolu University by the legislative decree law number 41 enacted on 2 July 1982. After that, the Open Education Faculty was founded within the body of Anadolu University by the law 2547 in 1983. The open education system, which initially started having two distance education programmes in the fields of Economics and Business Management during the 1982 and 1983 education years, has constantly extended its departments to a larger scale. In 1993, by the legislative decree law 496, the open education system was re-organised according to the requirements of the day and economics and management programmes were turned into four-year faculties (Demiray, 2013).

Radio School and Television School, serving under the Ministry of National Education between 1980 and 1990, was used for informal education. Open High School in 1992 and Open Elementary School in 1998 started to give education (Ozbay, 2015).

Firat University required the students to complete their master's thesis in electronic environments in 1990. METU started the first practices in its premises in 1997 and began to give synchronous education via the Internet in 2001.

The regulation on distance education was introduced by the Council of Higher Education in 1999 and the National Committee of Informatics was formed. Programmes and courses started within the scope of the regulation of distance education.

Primary education, which is compulsory education in Turkey, has been raised to 12 years from 8 years since 2012 (MONE, 2010). Therefore, open primary schools that gave education to 6th, 7th and 8th graders were also included in the scope of distance education. This changed its name to open secondary school instead of open elementary school.

Nowadays, distance education performs education more effectively on learning and teaching platforms, independent of time and physical location using computer and network technologies such as the Internet and Intranet. E-learning and the Project of Sharing and Accessing Information: The most significant purpose of distance education is to deliver more information to more people. E-learning models are as follows (Balaban, 2012). 
Mete, F., Buyukkose S., Cakir, O. \& Candeger, U. (2017). Graph representation of open and distance education history. Global Journal of Information Technology: Emerging Technologies. 7(3), 92-98.

- Television/Satellite/Open education

- Video conference

- Asynchronous learning

- Web or CD-ROM

- PC based, Internet, live virtual class

- Live sound and application sharing and video

- Mixed models

- Live virtual class + asynchronous + face-to-face.

\section{Graph Theory}

The foundation of graph theory was laid by Leonhard Euler through his article 'Seven Bridges of Konigsberg' (Isman, 2011). In the road map, there are certain routes showing how to go from one city to another. Consequently, two different clusters of objects are taken into consideration: Cities and (Buckley \& Frank, 1990).

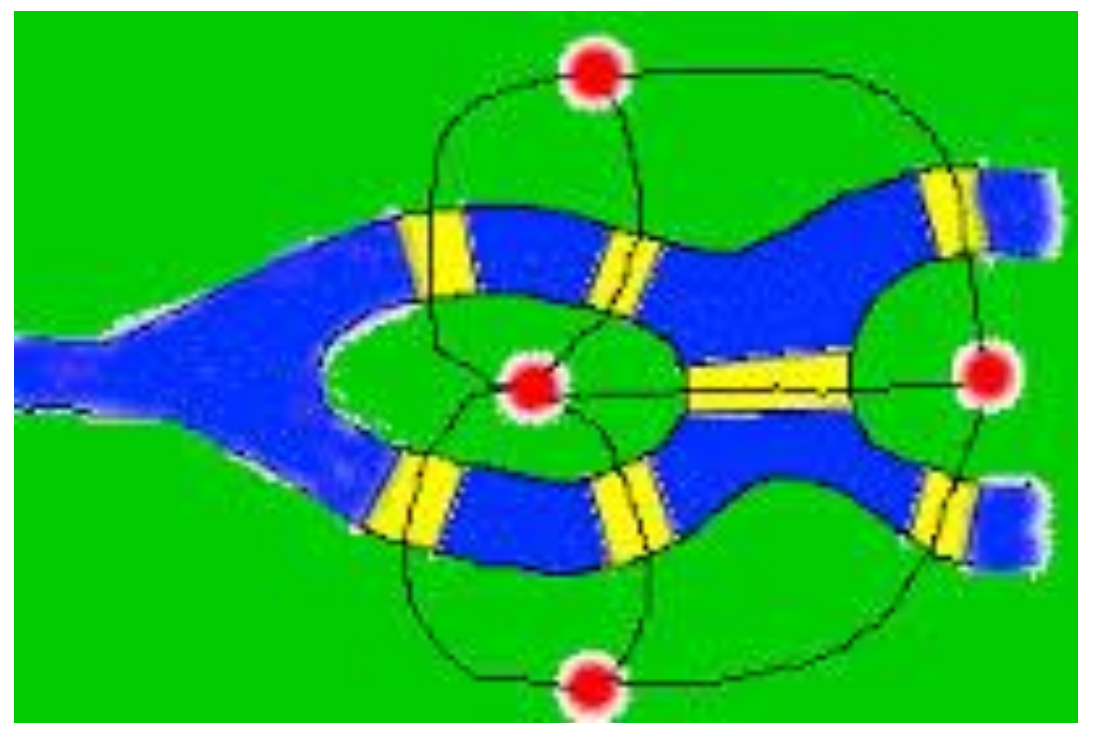

Figure 1. Seven Bridges of Konigsberg was drawn by Leonhard Euler

In graph theory, the clusters of any objects could be used to identify a relation (Bondy \& Uppaluri, 1976). When the cluster of cities was indicated with cluster $V$ and the cluster of roads with cluster $E$, if one travelled from city $a$ (point) to place $b$ (point) only using the roads in $\mathrm{E}$ over the cluster $\mathrm{V}, \mathrm{a}$ relation $\beta$ could be identified by writing $a \beta b$. If the roads in $\mathrm{E}$ are reversible lanes, it could also be identified as $b \beta a$. If all the roads are reversible lanes, this relation is symmetrical. One way of identifying a relation is to give its elements as ordered pairs in a list (Ellson, 2011).

Graph theory is considered as an effective method in chronological narratives of subjects and for presenting the connections between them through a network. Historical developments, connected vertically and horizontally, could be narrated in a chronological order through graph theory trees, and this makes it possible to see the big picture. It is aimed to make the subject more understandable by explaining the chronological development of open and distance education in the Turkish republic by using graph theory trees. Therefore, open and distance education is explained first, then historical information is given and in the conclusion, a graph theory tree drawn by using graph theory is used to explain the topic. 
Mete, F., Buyukkose S., Cakir, O. \& Candeger, U. (2017). Graph representation of open and distance education history. Global Journal of Information Technology: Emerging Technologies. 7(3), 92-98.

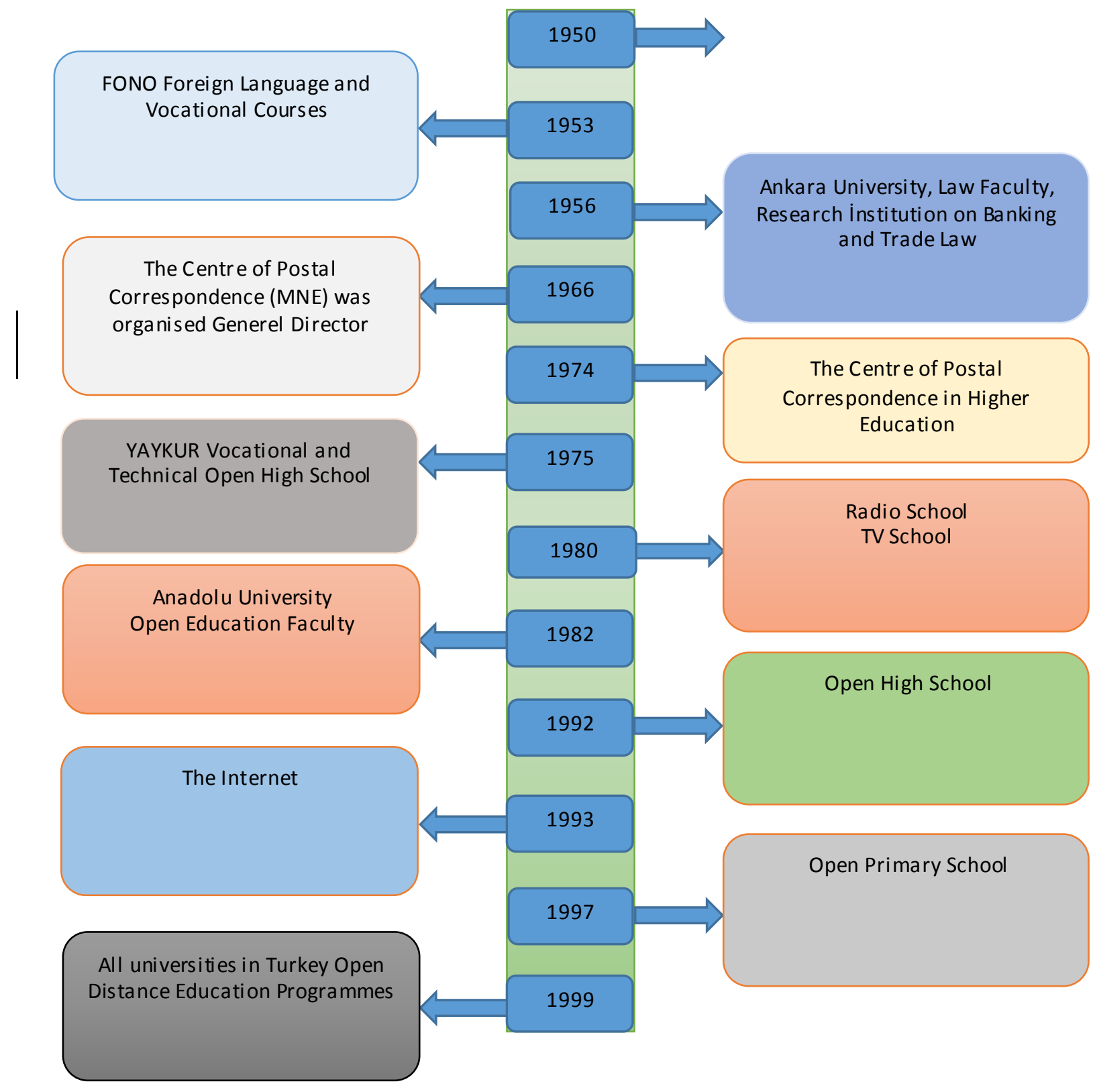


Mete, F., Buyukkose S., Cakir, O. \& Candeger, U. (2017). Graph representation of open and distance education history. Global Journal of Information Technology: Emerging Technologies. 7(3), 92-98.

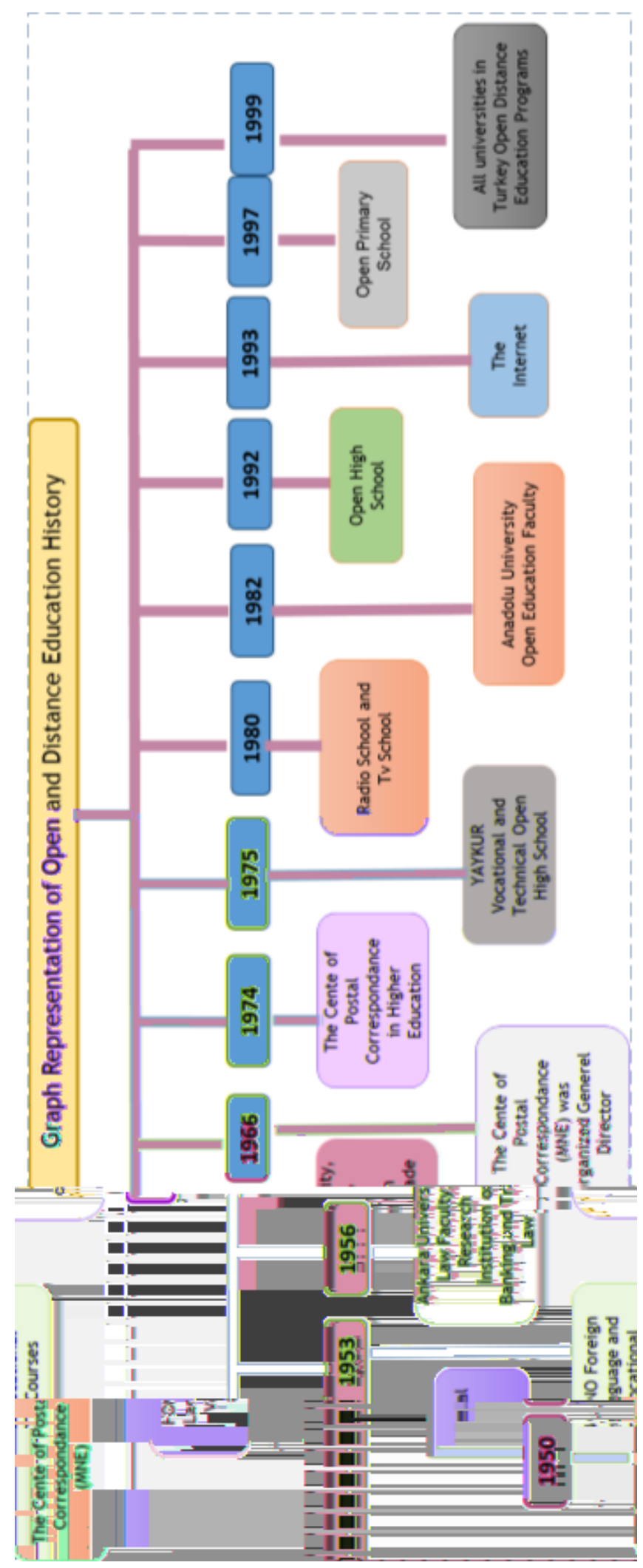

Figure 2. Graph representation of open and distance education history 
Mete, F., Buyukkose S., Cakir, O. \& Candeger, U. (2017). Graph representation of open and distance education history. Global Journal of Information Technology: Emerging Technologies. 7(3), 92-98.

\section{References}

Balaban, M. E. (2012). Dunyada ve Turkiye'de acik ve uzaktan ogren me ve bir proje onerisi. Access Date: 01 May 2016. http://erdalbalaban.com.tr/wp-content/uploads/2012/12/UEUzaktanE\%C4\%9FitimEB.pdf

Bondy, J. A., \& Uppaluri, S. R. M. (1976). Graph theory with applications. London: Macmillan.

Bornholdt, S., \& Heinz, G. S. (2002). Handbook of graphs and networks. Berlin: Wiley-Vch.

Buckley, F., \& Frank, H. (1990). Distance in graphs. London: Addison-Wesley Longman.

Degirmenci, H. (2013). Uzaktan egitim (E-Ogrenme veya E-Learning) sistemi ile egitimin akici ve duzenli bir sekilde verilmesi (Unpublished Master Graduation Project). Graduate School of Natural Sciences, Ege University, Izmir.

Demiray, E. (2013). Uzaktan egitim ve kadin egitiminde uzaktan egitimin onemi. Egitim ve Ogretim Arastirmalari Dergisi, 2(2), 2146-9199.

Ellson, J. (2011). Graphviz-Open source graph drawing tools: In Graph drawing. Berlin Heidel berg: Springer.

Holmberg, B. (2005). The evolution, principles and practices of distance education. Oldenburg: Bibliotheks- und Informations system der Universität Oldenburg.

Isman, A. (2011). Uzaktan egitim. Ankara: Pegem A Akademi .

Kesim, E., \& Altinpulluk, H. (2014). Perceptions of distance education professionals regarding the use of MOOCs. Turk. Online J. Qual. Inq., 5(4), 62-85.

MONE (2010). Distance education. Access Date: $05 \quad$ March 2016. http://egitek.meb.gov.tr/Kapaklink/UzaktanEgitim/UzaktanEgitim.html

pn 